\title{
STUDIES OF CYTOTOXICITY USING P32
}

\author{
by I. J. FORBES ${ }^{1,2}$ \\ (From the Department of Medicine (Thyroid Research Laboratory), \\ University of Michigan, Ann Arbor, Michigan).
}

(Accepted for publication 21st January, 1963.)

\section{SUMMARY.}

A technique is described for detecting damage to cells in culture using P32. The method is relatively simple and results obtained with it are reproducible.

The method depends on the principle that $\mathrm{P}^{32}$ passes from cells into a non-toxic medium at a rate which is a property of the particular type of cell. Cytotoxic agents cause an increased rate of leakage of $\mathrm{P}^{32}$ from cells.

The method was satisfactory with all of the cultures which were studied: the L-fibroblast, primary cultures of the 16-6 rat thyroid carcinoma and rat kidney, and subcultures of these rat cells.

Four types of cytotoxic agents were shown to cause an increased loss of $\mathrm{P}^{32}$ from the cells on which they were tested: the natural rat cytotoxin in rabbit serum, $\mathrm{NaOH}$, antisera to rat tissues, and mechlorethamine hydrochloride ("Mustargen").

Data are presented to show that increased $\mathrm{P}^{32}$ loss is due to cell damage.

\section{INTRODUCTION.}

Difficulties encountered in quantitating the effects of cytotoxic sera and lymphocytes on the Wollman 16-6 rat thyroid carcinoma in monolayer culture led to an investigation of the use of $\mathrm{P}^{32}$ for this purpose.

The method which has been developed has general application in the detection of cell damage induced by immunological and other agents, and in the study of the kinetics of antibody action. The principle upon which the method depends is simple. $\mathrm{P}^{32}$ passes from cells into normal medium at a rate which is a characteristic of the particular strain of cell. Several types of toxic substance which were investigated caused an increased rate of loss of $\mathrm{P}^{32}$ from cells.

Data are presented to demonstrate this principle, to show the sensitivity of the technique when it is used to detect cytotoxicity, and to show the reproducibility of the results obtained with it. Service.

${ }^{1}$ Fulbright Scholar, aided by Grant CA-05174-03 from the United States Public Health

2 Present address: Department of Microbiology, University of Adelaide, South Australia. 


\section{Materials and Methods.}

\section{Cell cultures.}

Primary monolayer cultures of the 16-6 transplantable rat thyroid carcinoma (Spicer, Wollman and Warren, 1960 $)^{3}$ were obtained using trypsin-dispersed cells. Stock cultures were subcultured by dispersing the cells with trypsin. Monolayer cultures of rat kidney cells were established using cells released by digestion of minced tissue with collagenase. Stock cultures were subcultured by dispersing the cells with trypsin. Cultures were established in Eagle's medium (L-strain modification, Difco Laboratories, Detroit, Michigan) and were maintained in Medium 199 (Morgan, Morton and Parker, 1950). 15 p.c. of foetal calf serum was used in all cultures. Cultures of a line of the mouse L-fibroblast ${ }^{4}$ were also used. These were maintained in Medium 199 containing 15 p.c. foetal calf serum. For use in tests $1 \mathrm{ml}$. volumes, containing $10^{5}$ cells in subcultures and $10^{6}$ cells in primary cultures, were inoculated in screw-capped tissue culture tubes in a sloping position for 24 hours at $37^{\circ} \mathrm{C}$. The medium was then replaced by $4 \mathrm{ml}$. of the same material and the tubes were incubated vertically. The medium was subsequently changed twice weekly. Two $\mathrm{ml}$. of cells were inoculated into vertical tubes in later experiments, and $2 \mathrm{ml}$. of medium were used throughout.

\section{Incorporation of $\mathrm{P}^{32}$.}

The medium in established cultures was changed for one containing $2 \mu \mathrm{c}$. per ml. of $\mathrm{P}^{32}$ as trisodium phosphate (Abbott Laboratories, Radio-Pharmaceuticals, Oak Ridge, Tennessee). After 24 hours at $37^{\circ} \mathrm{C}$. the cells were washed twice with $4 \mathrm{ml}$. of 199 solution.

Use of cells which have incorporated $P^{32}$.

Media containing serum, lymphocytes or substances to be tested for cytotoxicity were added in $4 \mathrm{ml}$. volumes to cultures, and control tubes containing normal serum or cell suspensions were set up at the same time. Tubes were incubated at $37^{\circ} \mathrm{C}$. for the period of time considered necessary for the completion of the reaction or for the development of detectable cell damage.

\section{Measurement of $P^{32}$.}

Since $\mathrm{P}^{32}$ is a pure beta-emitter with a maximum energy of $1.7 \mathrm{mev}$., a scintillation well-type counter was used to measure Bremsstrahlung radiation. Using a pulse-height analyser, all energies above $0.01 \mathrm{mev}$, were detected. Total P32 counts were usually 20 times background. After measuring the total $\mathrm{P}^{32}$ activity the medium was poured off. The cells were washed twice by pouring in $4 \mathrm{ml}$. of phosphate buffered saline (PBS) (Dulbecco and Vogt, 1954). The pooled medium and washings were centrifuged at 2000 r.p.m. for five minutes and a $4 \mathrm{ml}$. aliquot was pipetted off for counting. The results were expressed as the percentage of the total $\mathrm{P}^{32}$ which had passed from the cells into the medium.

\section{Measurement of $P^{32}$ in trichloroacetic acid precipitate of medium.}

An equal volume of cold 20 p.c. trichloroacetic acid (TCA) was added to the pooled medium from replicate cultures. The precipitate was centrifuged at 2500 r.p.m. for five minutes, and washed twice by resuspending in 10 p.c. TCA and centrifuging. The washed precipitate was dissolved in 10 p.c. $\mathrm{NaOH}$ for counting.

\section{Cell counts.}

In an experiment in which the counts of $\mathrm{P} 32$ in washed cells were compared with the total cell counts of the corresponding cultures, cells were removed from the glass for counting

3 Obtained from Dr. S. H. Wollman, National Institutes of Health, Bethesda, Maryland.

4 Obtained from Dr. D. J. Merchant, Department of Bacteriology, University of Michigan, Ann Arbor, Michigan. 
by changing the medium for 199 solution containing $0 \cdot 15$ p.c. trypsin at $\mathrm{pH} 7 \cdot 6$. The tubes were agitated gently in a Dubnoff incubator at $37^{\circ} \mathrm{C}$. for 30 minutes. Three counts were made in a Coulter Model A counter (Coulter Electronics, Chicago, Illinois), and averaged.

\section{RESULTS.}

The rate of $P^{32}$ loss from cells.

Fig. la shows the total $\mathrm{P}^{32}$ counts and the proportions of these counts due to $\mathrm{P}^{32}$ in medium and cells, in an experiment in which replicate primary cultures of 16-6 rat thyroid carcinoma were subjected, after incubation with $\mathrm{P}^{32}$, to the action of 30 p.c. normal rabbit serum $\mathrm{A}$, and to 10 p.c. $\mathrm{NaOH}$, for 18 hours. Fifteen p.c. foetal calf serum in medium 199 was used as the control in the experiments to be described, as this combination was the best which had been found for the growth of the 16-6 and rat kidney cells.

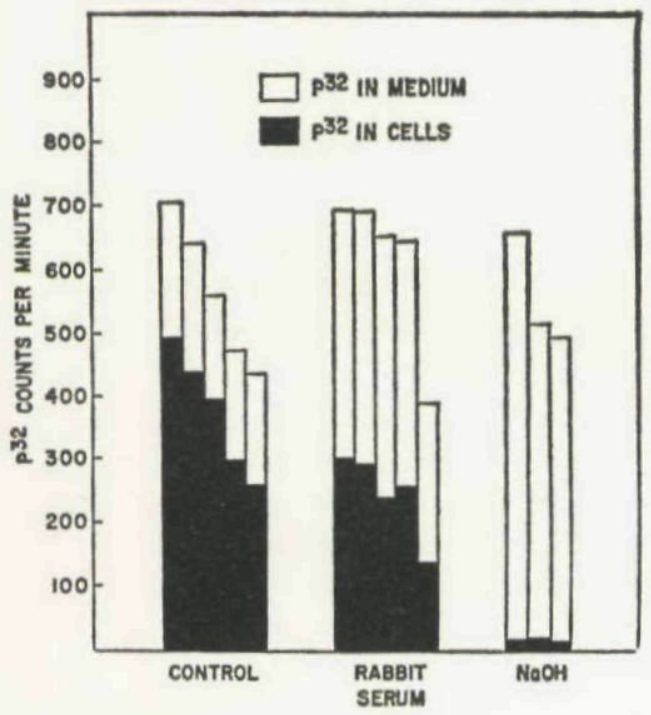

Fig. la.

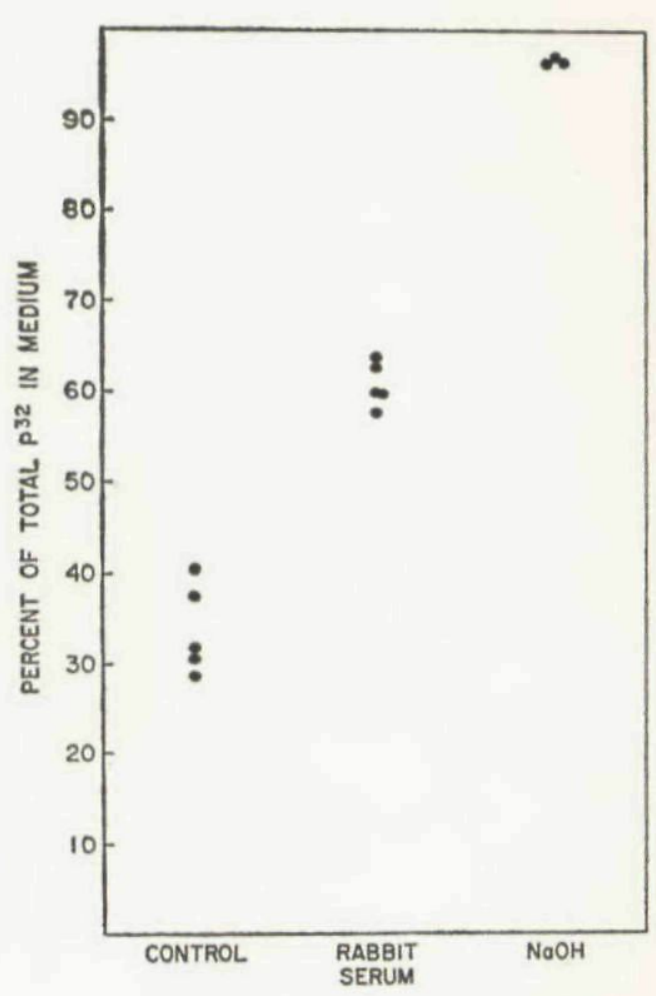

Fig. 1b.

Fig. 1a. The counts of $\mathrm{P}^{32}$ in cells (solid bars) and medium (open bars) in replicate cultures incubated in 15 p.c. foetal calf serum, 30 p.c. rabbit serum $\mathrm{A}$ and 10 p.c. $\mathrm{NaOH}$ for 18 hours.

Fig. 1b. The data expressed as the percentage of the total $\mathrm{P}^{32}$ which had passed into the medium at 18 hours. 
The total $\mathrm{P}^{32}$ counts, and hence the $\mathrm{P}^{32}$ in the cells at the beginning of the test, varied greatly from tube to tube. The variation in the number of cells in the tubes undoubtedly contributed to this (see Fig. 4). These data show that absolute figures of counts per minute from cells or medium cannot be used to assess the effect of a mildly cytotoxic agent, since the individual variation may be greater than the change caused by the agent.

Fig. $1 b$ illustrates, however, that the amount of $\mathrm{P}^{32}$ leaving the cells of the culture in normal medium was proportional to the original $\mathrm{P}^{32}$ content of the

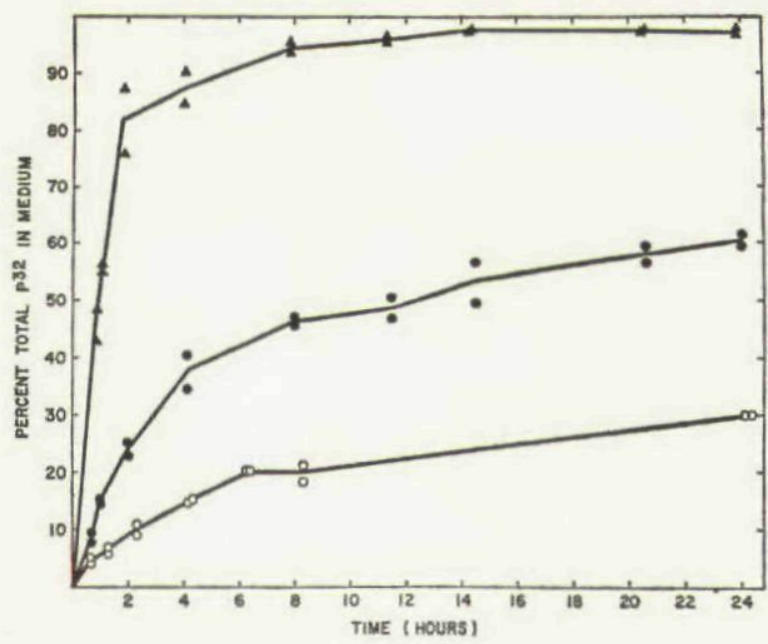

Fig. 2. The percentage of the $\mathrm{P}^{32}$ which passed into the medium at increasing intervals of incubation of cells which had incorporated $\mathrm{P} 32$. Open circles represent the data obtained with L-fibroblasts and solid circles the results with 16-6 cells in normal medium. The triangles plot results obtained with cultures of 16-6 cells in 10 p.c. fresh rabbit serum. Each point represents the result of one culture. The curves are drawn through the mean of each pair of observations.

cells. The percentage of the total $\mathrm{P}^{32}$ which had passed into the medium fell within a narrow range in replicate cultures. This relationship held over a wide range of $\mathrm{P}^{32}$ uptakes.

Not only did the cell- $\mathrm{P}^{32}$ percentages of replicate cultures in the same experiment fall within a narrow range, but also other comparable experiments carried out over the same reaction time gave results which were in the same range (Table 1).

The amount of $\mathrm{P}^{32}$ passing into the medium varied with the reaction time (Table 1, Fig. 2). The rate of loss of $\mathrm{P}^{32}$ from the mouse L-fibroblast was less than from 16-6 cells. With both cell types there was an initial relatively rapid release of $\mathrm{P}^{32}$ and a steady rate of $\mathrm{P}^{32}$ loss after four hours in normal medium. A similar rate of release of $\mathrm{P}^{32}$ from 16-6 cells occurred in media containing sera of other species (see Table 1), and in physiological saline containing 15 p.c. foetal calf serum.

Effect of cytotoxic factors.

Addition of a cytotoxic serum caused an increase in the amount of $\mathrm{P}^{32}$ leaving the cells. The rat-cell toxin occurring naturally in fresh rabbit serum (Terasaki et al., 1961) was used in many of these experiments. Normal rabbit 
TABLE 1.

The percentage of total $P^{32}$ in the medium. Experiments with non-toxic sera.

\begin{tabular}{|c|c|c|c|c|c|}
\hline Cells & Serum in medium 199 & $\begin{array}{l}\text { Reaction } \\
\text { time }\end{array}$ & $\begin{array}{c}\text { Number } \\
\text { of } \\
\text { tubes }\end{array}$ & $\begin{array}{c}\text { p.c. of } \\
\text { total } \mathrm{P}^{32} \\
\text { in medium }\end{array}$ & $\begin{array}{l}\text { Standard } \\
\text { deviation }\end{array}$ \\
\hline $16-6$ & 15 p.c. foetal calf & 20 mins. & 4 & $8 \cdot 8$ & $2 \cdot 1$ \\
\hline $16-6$ & 15 p.c. foetal calf & 3 hours & 3 & $25 \cdot 4$ & $4 \cdot 5$ \\
\hline $16-6$ & 15 p.c. foetal calf & 3 hours & 5 & $27 \cdot 6$ & $2 \cdot 4$ \\
\hline $16-6$ & 15 p.c. foetal calf & 3 hours & 5 & $30 \cdot 4$ & $2 \cdot 1$ \\
\hline $16-6$ & 15 p.c. foetal calf & 3 hours & 4 & $30 \cdot 0$ & $1 \cdot 9$ \\
\hline $16-6$ & 15 p.c. foetal calf & 3 hours & 4 & $22 \cdot 4$ & $1 \cdot 1$ \\
\hline $16-6$ & 15 p.c. heated foetal calf & 3 hours & 4 & $30 \cdot 2$ & $2 \cdot 1$ \\
\hline 16.6 & 10 p.c. guinea pig & 3 hours & 4 & $28 \cdot 2$ & $3 \cdot 1$ \\
\hline $16-6$ & 20 p.c. guinea pig & 3 hours & 4 & $21 \cdot 4$ & $2 \cdot 1$ \\
\hline $16-6$ & $\begin{array}{l}10 \text { p.c. heated rabbit } \\
10 \text { p.c. guinea pig }\end{array}$ & 3 hours & 4 & $25 \cdot 4$ & $2 \cdot 8$ \\
\hline $16 \cdot 6$ & $\begin{array}{l}10 \text { p.c. heated rabbit } \\
10 \text { p.c. guinea pig }\end{array}$ & 3 hours & 4 & $25 \cdot 1$ & $2 \cdot 5$ \\
\hline 16.6 & $\begin{array}{l}5 \text { p.c. heated rabbit } \\
5 \text { p.c. guinea pig }\end{array}$ & 3 hours & 5 & $30 \cdot 1$ & $2 \cdot 1$ \\
\hline $\begin{array}{l}\text { Rat } \\
\text { kidney }\end{array}$ & $\begin{array}{l}5 \text { p.c. heated rabbit } \\
5 \text { p.c. guinea pig }\end{array}$ & 3 hours & 5 & $30 \cdot 4$ & $2 \cdot 1$ \\
\hline $\begin{array}{c}\text { Rat } \\
\text { kidney }\end{array}$ & 15 p.c. foetal calf & 3 hours & 5 & $32 \cdot 9$ & $7 \cdot 9$ \\
\hline $16-6$ & 15 p.c. foetal calf & 18 hours & 5 & $42 \cdot 8$ & $1 \cdot 6$ \\
\hline 16-6 & 15 p.c. foetal calf & 18 hours & 5 & $33 \cdot 7$ & $5 \cdot 0$ \\
\hline $16-6$ & 10 p.c. normal rat & 18 hours & 5 & $42 \cdot 3$ & $2 \cdot 5$ \\
\hline $\begin{array}{l}\text { Rat } \\
\text { kidney }\end{array}$ & 15 p.c. foetal calf & 18 hours & 5 & $46 \cdot 4$ & $4 \cdot 8$ \\
\hline $16-6$ & $\begin{array}{l}15 \text { p.c. heated rabbit } \\
15 \text { p.c. guinea pig }\end{array}$ & 22 hours & 5 & $54 \cdot 7$ & $2 \cdot 3$ \\
\hline L-cells & 15 p.c. foetal calf & 3 hours & 5 & $11 \cdot 5$ & 0.8 \\
\hline L-cells & 1 p.c. peptone no serum & 3 hours & 5 & $8 \cdot 1$ & $1 \cdot 1$ \\
\hline L-cells & 15 p.c. foetal calf & 22 hours & 4 & $20 \cdot 2$ & $1 \cdot 3$ \\
\hline L-cells & 15 p.c. foetal calf & 24 hours & 5 & $30 \cdot 2$ & $2 \cdot 2$ \\
\hline
\end{tabular}

serum A caused visible damage to monolayers of rat cells (increased granularity of the cytoplasm, ballooning of the cell membrane and lysis of some cells), but when added to cultures even in 30 p.c. concentration at least half of the cells survived at 24 hours. Other fresh normal rabbit sera (B, C) were more toxic.

Increased $\mathrm{P}^{32}$ loss correlated in all instances with the presence of cytotoxic effects, and the severity of the observed cell damage was reflected in the extent of $\mathrm{P}^{32}$ loss.

Fig. 3 shows the effects of adding 7.5 p.c., 15 p.c. and 30 p.c. concentrations of fresh rabbit serum B to groups of replicate cultures for three hours. The percentage of $\mathrm{P}^{32}$ released into the medium and the observed cell damage were proportional to the concentration of serum used.

The effect of heat stable antibody in the presence of complement, after incubation at $37^{\circ} \mathrm{C}$. for 22 hours, is shown in Table 2. Rabbit antiserum 2 to an antigen prepared from pooled Fischer rat kidney, liver and spleen, and rabbit 
antiserum 249 to another transplantable Wollman carcinoma (1-5A tumor) were compared with control tubes containing normal rabbit serum C. All sera were inactivated at $56^{\circ} \mathrm{C}$. for 30 minutes, and were used in the test at 15 p.c. concentration in the presence of 15 p.c. of fresh guinea pig serum. The natural rabbit heterotoxin is inactivated by this treatment. Cytotoxic effects were visible in the cultures containing sera 2 and 249 , but no damage was seen in the control tubes.

Results with mechlorethamine hydrochloride ("Mustargen", Merck, Sharpe and Dohme, Philadelphia, Pennsylvania) are also shown in Table 2. An inverse relationship is seen between $\mathrm{P}^{32}$ release and the concentration of drug in the medium in the range in which it was tested. These results clearly corresponded with the cytotoxic effects seen microscopically. Fig. 1 shows the effect of incubating the cells in 10 p.c. $\mathrm{NaOH}$.

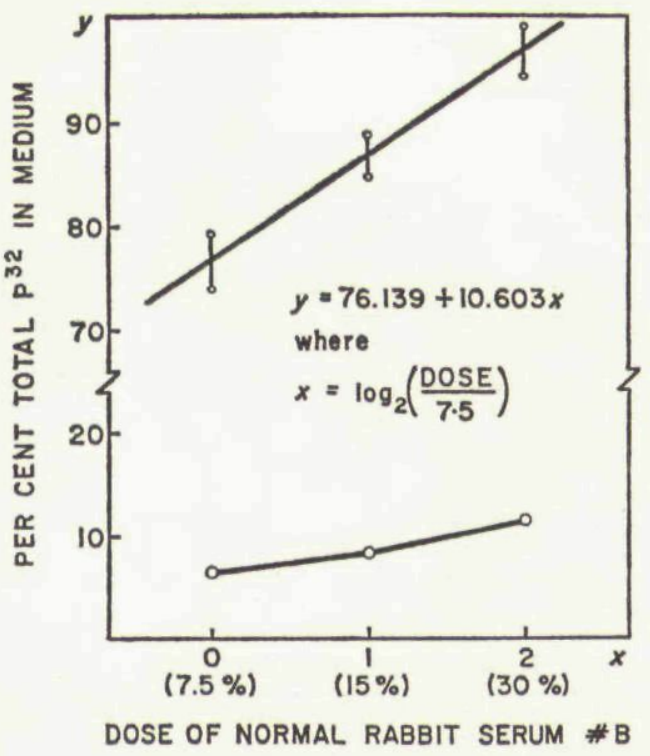

Fig. 3. The upper curve is the regression line plotted from data obtained when 16-6 cells were incubated in 7.5 p.c., 15 p.c. and 30 p.c. normal rabbit serum B for three hours. Five cultures were used in each group. The bars represent the standard error for the mean. The points of the lower curve are values of the TCA-precipitable $\mathrm{P}^{32}$ expressed as a percentage of the total $\mathrm{P}^{32}$, in the pooled media in each group,

TABLE 2.

Effect of cytotoxic factors. Percentage of $P^{32}$ in medium.

\begin{tabular}{|c|c|c|c|c|}
\hline \multirow[b]{2}{*}{ Cell type } & \multirow{2}{*}{$\begin{array}{c}\text { Incubation } \\
\text { period } \\
\text { hours }\end{array}$} & \multirow[b]{2}{*}{ Toxic agent } & \multicolumn{2}{|c|}{ Percentage $\mathrm{P}^{32}$ in medium } \\
\hline & & & Control S.D.* & Test S.D.* \\
\hline $16-6$ & 18 & 30 p.c. N.R.S. ${ }^{* *} \mathrm{~A}$ & $33 \cdot 7 \pm 5 \cdot 0$ & $60 \cdot 7 \pm 2 \cdot 6$ \\
\hline 16-6 & 20 & 30 p.c. N.R.S. A & $42 \cdot 8 \pm 1 \cdot 6$ & $72 \cdot 7 \pm 2 \cdot 2$ \\
\hline Rat kidney & 3 & 30 p.c. N.R.S. & $32 \cdot 9 \pm 7 \cdot 9$ & $85 \cdot 4 \pm 3 \cdot 8$ \\
\hline Rat kidney & 18 & 30 p.e. N.R.S. B & $46 \cdot 4 \pm 4 \cdot 8$ & $93 \cdot 5 \pm 2 \cdot 9$ \\
\hline L-fibroblast & 3 & 27.5 p.c. N.R.S. C & $8 \cdot 6 \pm 1 \cdot 1$ & $25 \cdot 2 \pm 3 \cdot 6$ \\
\hline \multirow{2}{*}{$16 \cdot 6$} & 22 & Antiserum 2 & $54 \cdot 7 \pm 2 \cdot 3$ & $73 \cdot 6 \pm 2 \cdot 4$ \\
\hline & & Antiserum 249 & $54 \cdot 7 \pm 2 \cdot 3$ & $76 \cdot 9 \pm 3 \cdot 1$ \\
\hline \multirow[t]{3}{*}{ L-fibroblast } & 24 & Mustargen $\times 100 \mu \mathrm{g} . / \mathrm{ml}$. & $30 \cdot 2 \pm 2 \cdot 9$ & $35 \cdot 1 \pm 4 \cdot 7$ \\
\hline & & Mustargen $\quad 50 \mu \mathrm{g} . / \mathrm{ml}$. & $30 \cdot 2 \pm 2 \cdot 9$ & $45 \cdot 5 \pm 3 \cdot 3$ \\
\hline & & Mustargen & $30 \cdot 2 \pm 2 \cdot 9$ & $58 \cdot 5 \pm 1 \cdot 8$ \\
\hline \multirow[t]{3}{*}{ L-fibroblast } & 22 & Mustargen $100 \mu \mathrm{g} . / \mathrm{ml}$. & $20 \cdot 2 \pm 1 \cdot 3$ & $29 \cdot 7 \pm 2 \cdot 2$ \\
\hline & & Mustargen & $20 \cdot 2 \pm 1 \cdot 3$ & $34 \cdot 9 \pm 5 \cdot 1$ \\
\hline & & Mustargen & $20 \cdot 2 \pm 1 \cdot 3$ & $45 \cdot 8 \pm 5 \cdot 0$ \\
\hline
\end{tabular}

* Standard deviation.

** Normal Rabbit Serum.

$\times$ Mechlorethamine hydrochloride. 
The medium contained 97 p.c. of the $\mathrm{P}^{32}$. Microscopically there was complete destruction of the cells.

Relationship of $P^{s z}$ counts to number of cells.

Fig. 4 shows the correlation obtained when washed 16-6 cells were counted after their $\mathrm{P}^{32}$ content was me a sured. Substantial error in counting the cells was due to the fact that a small fraction of cells could not be dislodged in most tubes. Nevertheless, the correlation coefficient was $0 \cdot 77$ corresponding to a $p$ value of less than $0 \cdot 005$.

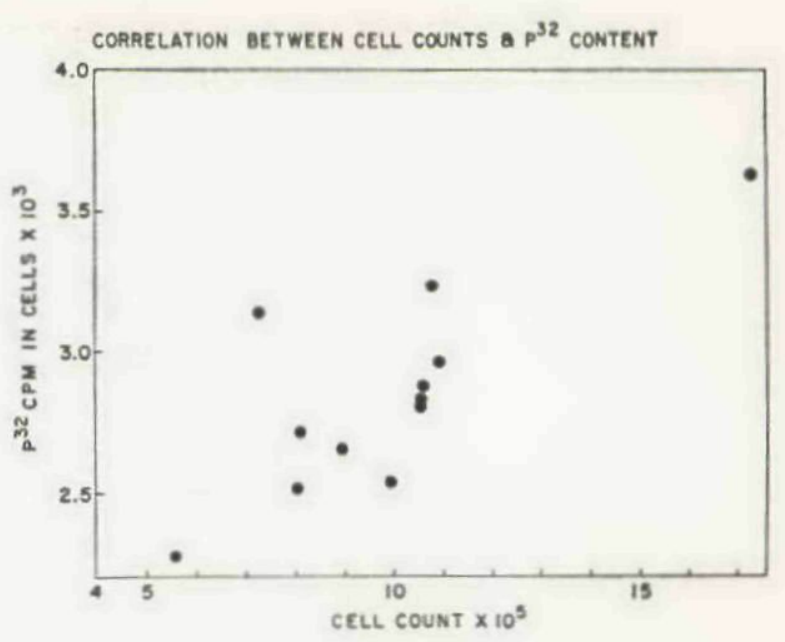

Fig. 4. Correlation between cell counts and P32 content. The $\mathrm{P}^{32}$ counts from washed 16-6 cells are plotted against the cell count of the corresponding culture. The cells were released from glass by treatment with trypsin and then counted in an electronic cell counter.

\section{Use of other cell types.}

In experiments using cultures of Fischer rat kidney, $\mathrm{P}^{32}$ uptake, normal rate of loss of $\mathrm{P}^{32}$ from cells, and results on exposure to rabbit serum were similar to those obtained with 16-6 cells. The rate of loss of $\mathrm{P}^{32}$ from L-fibroblast was less than from the rat cells in a non-toxic medium, but inclusion of fresh normal rabbit serum in the medium caused visible damage and an increased $\mathrm{P}^{32}$ loss (Table 2).

\section{Comparison with $P^{s 2}$ in TCA precipitate.}

The TCA precipitate of the control medium did not contain measurable $\mathrm{P}^{32}$ in six experiments, but in six tests in which there was visible cell damage and an increased $\mathrm{P}^{32}$ loss from the cells, a proportion of this $\mathrm{P}^{32}$ was found in the TCA precipitate.

The $\mathrm{P}^{32}$ which was precipitated from the medium, expressed as a percentage of the total $\mathrm{P}^{32}$, is compared with the percentage of the total $\mathrm{P}^{32}$ in the medium in Fig. 5. The coefficient of correlation is 0.89 (significant at the 1 p.c. level).

The TCA-precipitable $\mathrm{P}^{32}$ was also shown to be proportional to the concentration of fresh rabbit serum in the medium (Fig. 3). 


\section{DISCUSSION.}

There is need for a simple method of detecting damage to cells in monolayer culture with which objective, numerical data can be obtained. The method involving the use of $\mathrm{P}^{32}$ was developed for study of cytotoxicity of antisera to malignant cells, for analysis of the surface antigens of these cells, and for detection of lytic activity in vitro of lymphocytes sensitized to homologous cells. It will provide a parameter for gauging the rate of cytotoxic reactions, and may be valuable in studying the kinetics of the action of complement on cells in culture. Experiments with nitrogen mustard showed that the cytotoxic action of drugs used for cancer chemotherapy may be detected.

A direct assessment of the number of cells destroyed by a cytotoxic agent may be obtained by comparing cell counts of cultures after the action of the agent, with the cell counts of identical control cultures (Rosenau and Moon, 1961). This method could not be used with 16-6 and rat kidney cultures because cells could not be dislodged completely from glass, and there was a great variation in the number of cells in replicate cultures.

The studies which have been reported in this paper show that $\mathrm{P}^{32}$ passes from cells into a normal medium at a rate which is characteristic of the type of cell, and that the loss is accelerated when cells are damaged. It is, therefore, not necessary, when comparing the effects of substances on the rate of $\mathrm{P}^{32}$ loss, to have identical numbers of cells in the replicate cultures, since the rate of loss is determined by measuring the ratio of $\mathrm{P}^{32}$ in the medium to the total $\mathrm{P}^{32}$ (i.e. that which was in the cells at the beginning of the test).

The rate at which $\mathrm{P}^{32}$ passed into the normal medium was slower with the L-fibroblast than with the cultures of rat cells which were used. The initial more rapid loss of $\mathrm{P}^{32}$ from the 16-6 and rat kidney cells may be due to a small amount of toxic substance in the fresh "normal" medium. However, the rate of $\mathrm{P}^{32}$ loss in the first four hours was not influenced by reducing the phosphate concentration of the medium, or by heating the foetal calf serum used in the 
medium. The rate was similar in Eagle's basal medium, and medium 199 with foetal calf serum; also in media containing fresh or heated guinea pig serum, fresh rat serum, and heated rabbit serum. The rate of $\mathrm{P}^{32}$ loss may be a useful index of the suitability of the culture medium.

There can be little doubt that loss of $\mathrm{P}^{32}$ greater than that occurring in control cultures results from injury to cells. The correlation of cell numbers with counts of the $\mathrm{P}^{32}$ within the cells is evidence that loss of $\mathrm{P}^{32}$ is due to destruction of cells. Furthermore, microscopic evidence of cell damage was always seen in cultures where $\mathrm{P}^{32}$ loss was accelerated. However, it is possible that slight injury to cells may cause an increased rate of $\mathrm{P}^{32}$ release without killing them. $\mathrm{P}^{32}$ which can be precipitated from the medium by trichloroacetic acid apparently comes from within the cells as it was only detected in the medium when cells had been visibly damaged. The release of TCA-precipitable $\mathrm{P}^{32}$ was proportional to the total amount of $\mathrm{P}^{32}$ released. Also, in the case of the natural rat cytotoxin found in rabbit serum, the $\mathrm{P}^{32}$ release was proportional to the concentration of the toxin in the medium.

Other cytotoxic agents were tested: antisera to rat tissues containing heatstable antibody, $\mathrm{NaOH}$, and mechlorethamine hydrochloride ("Mustargen"). Each caused an increased rate of $\mathrm{P}^{32}$ loss from appropriate cells.

Results with nitrogen mustard show a curious effect: in the dosages which were used the cytotoxic effect varied inversely with the concentration of the drug. The technique should be valuable in the study of chemotherapeutic agents.

Ellem (1958) showed that damage by antibody and complement quickly caused the loss of most of the phosphate from tumour cells in suspension. Green et al. (1959) have established that radioactive potassium $\left(\mathrm{K}^{42}\right)$ passes from living cells into the culture medium at a steady rate, as has been shown for $\mathrm{P}^{32}$. Similarly, damage to cells causes an increased rate of loss of $\mathrm{K}^{42}$. Other workers have utilised the loss of radioactive isotopes from cells as an index of cell damage. Magee, Sheek and Sagik (1958) showed that $\mathrm{C}^{14}$ and $\mathrm{S}^{35}$ were released from cells in culture in the procedure of harvesting cells either with trypsin or by scraping. Levine (1960) used $\mathrm{P}^{32}$ to study the effects of repeated washings with different solutions at short intervals on the integrity of cells in monolayer culture. He showed that the presence of serum in the medium used to wash the cells protected against an increased loss of $\mathrm{P}^{32}$ from the cells in the third and subsequent washes. He also showed that trypsin caused an increased loss of $\mathrm{P}^{32}$, and that part of the $\mathrm{P}^{32}$ of media containing increased amounts of $\mathrm{P}^{32}$ was precipitated by trichloroacetic acid. Perlmann, Broberger and Klein (1962) used the activity of $\mathrm{C}^{14}$ bound to protein in the medium as an index of cell damage. They have also used $\mathrm{P}^{32}$ in the same way (Perlmann, 1962).

The technique which has been described in this paper yields results which correspond to those obtained by measuring the acid-insoluble isotope content of the medium, and has advantages of simplicity and accuracy which accompany the performance of multiple determinations. In addition, in the case of minimal 
damage to cells the release of TCA insoluble $\mathrm{P}^{32}$ is accompanied by the release of many times more soluble $\mathrm{P}^{32}$, so that there is a greater margin between the radioactivity of the sample to be counted and the level of background radioactivity. The operations are greatly simplified by counting Bremsstrahlung radiations in a well-type scintillation counter from tubes containing monolayers and medium in the first count, and separated medium in the second, instead of measuring the beta emission from dried aliquots of lysed cells and medium in planchets.

Acknowledgments. The help of Dr. W. H. Beierwaltes, Director of the Thyroid Research Laboratory, University of Michigan, is gratefully acknowledged. Dr. D. J. Merchant of the Department of Bacteriology, University of Michigan, helped generously with technical advice, criticism and a supply of L-fibroblasts. The helpful criticisms of Dr. R. J. Porter of the School of Public Health, University of Michigan, are much appreciated. Statistical analyses were carried out by Dr. M. E. Patno of the School of Public Health of this University. The technical assistance of Mr. Arthur Smiltens was invaluable. The Wellcome Trust, London, gave support in the form of a travel grant.

\section{REFERENCES.}

Dulbecco, R., and Vogt, M. (1954): J. exp. Med., 99, p. 167.

Ellem, K. A. O. (1958): Cancer Res., 18, p. 1179.

Green, H., Fleischer, R. A., Barrow, P., and Goldberg, B. (1959): J. exp. Med., 109, p. 511. Levine, S. (1960): Exper. Cell Res., 19, p. 220.

Magee, W. E., Sheek, M. R., and Sagik, B. P. (1958): Proc. Soc. exp. Biol., 99, p. 390.

Morgan, J. F., Morton, H. J., and Parker, R. C. (1950): Ibid., 73, p. 1.

Perlmann, P. (1962): Personal communication.

Perlmann, P., Broberger, O., and Klein, E. (1962): Fed. Proc., 21, p. 12.

Rosenau, W., and Moon, H. D. (1961): J. Nat. Cancer Inst., 27, p. 471.

Spicer, S. S., Wollman, S. H., and Warren, L. (1960): Amer. J. Path., 37, p. 599.

Terasaki, P. I., Esail, M. L., Cannon, J. A., and Longmire, W. P., Jr. (1961): J. Immunol., 87 , p. 383. 
This document is a scanned copy of a printed document. No warranty is given about the accuracy of the copy. Users should refer to the original published version of the material. 